\title{
Do the Descendants of European Immigrants Still Speak their Ancestral Languages in Paraná (Brazil)?
}

\author{
By Clarice Cristina Corbari*
}

\begin{abstract}
This paper presents some research results on language attitudes of speakers from seven communities in Paraná, a state in the south of Brazil settled mainly by European immigrants and descendants. The study aims to identify the current situation of bilingualism in these communities and language attitudes toward immigration languages. Data were collected through interviews based on a questionnaire covering three components of attitude: cognitive, affective, and conative (Lambert \& Lambert 1966). The results showed that the attitudes of respondents toward the languages or varieties (including their own) are mainly positive. However, there has been a generational shift to the Portuguese, resulting in residual bilingualism, even though the attitudes toward bi-and multilingualism are positive.
\end{abstract}

Keywords: Bilingualism, Language attitudes, Language contact

\section{Introduction}

In the eighteenth century and early nineteenth century, a large amount of European (non-Portuguese) people immigrated to Brazil. Most of the immigrants settled in the southern states of Rio Grande do Sul, Santa Catarina and Paraná. Studies on language maintenance and language shift in communities of immigrant descendants in this Brazilian region (Ogliari 2001, Fraga 2008, Pertile 2009) have pointed that, in most of the cases, the use of immigrant languages has been declining since they are not being transmitted to the following generations. In Sociolinguistics, it is generally assumed that the decline of a language can be tied to the speakers' attitudes, which play a significant role in the process of language maintenance and language shift.

The process of building a national identity in Brazil has certainly contributed to the decreasing of use of immigrant languages (Bolognini \& Payer 2005, Renk 2009, Oliveira \& Altenhofen 2011). Language policies promoting Portuguese as the official and national language resulted in the shrinkage of immigrant languages in Brazil. In the past, Brazil implemented a monolingualizing language policy with various measures of controlling linguistic diversity, such as the nationalization campaigns of the 1930s, i.e. the process of defining a national identity by applying educational policies focused heavily on teaching Portuguese as the only language, and by emphasizing its use in all public spaces. This process constituted the ideological construction of "brasilidade", or Brazilness (Orlandi 1998).

Studies in communities of immigrant descendants in the south of Brazil (Krug 2004, Luersen 2009) show that the maintenance of the ancestral ${ }^{1}$ language is also linked to the socio-geographic organization: where the communities formed language islands - i.e. exclaves of a language distinguished from the one(s) spoken in the vicinity - or where the contingent of a given ethnic group was more

\footnotetext{
* Professor and Researcher, State University of West of Paraná, Brazil.

${ }^{1}$ In this article, "ancestral languages" refers specifically to the immigrant languages.
} 
representative, the speakers of the immigrant languages have been more resistant to linguistic substitution. Obviously, there are also other factors involved, such as the role of religion, especially among Germans, Poles and Ukrainians (Krug 2004, Renk 2009).

This paper presents an investigation on language attitudes carried out in seven communities in Paraná, colonized by European immigrants and descendants and, therefore, characterized by language contact between Portuguese and immigration languages. Moreover, five of these locations are bordering Spanish-speaking countries, resulting in the contact between Spanish and Portuguese. The data were based on interviews collected in fieldwork for a larger comparative project coordinated by Aguilera (2009) and analyzed according to theoretical and methodological principles of Sociolinguistics, Social Psychology and Sociology of Language. The specific aim is to identify the current situation of bilingualism in these communities and the speakers' attitudes toward the use and maintenance of immigration languages. It should be mentioned that some of the communities have been already studied by researchers for their Master or Doctoral thesis (SilvaPoreli 2010, Pastorelli 2011, Lamb Fenner 2013 Corbari 2013).

\section{Theoretical Background}

This study is based on the assumption that language is closely related to ethnic identity (Fishman 1972a, Spolski 1998, Dorian 1999, Liebkind 1999) and, consequently, attitudes toward a particular language reflect attitudes toward its speakers (Moreno Fernández 1998). People have behaviors, feelings and beliefs about language in general, their own language, and the language of other people. According to Lambert \& Lambert (1966), an attitude is an organized and coherent way to think, feel, and react to people, groups, social issues or, more generally, any event that takes place in our surroundings. It is constituted by three components, namely the cognitive (thoughts and beliefs), the affective (feelings or emotions) and the conative or behavioral (tendency to react) components. An attitude is formed when these components are tied in such a way that the feelings and the specific reactive tendencies are consistently associated with a particular way of thinking in certain people, phenomena or events. This concept of attitude as a complex entity constitutes the mentalist approach, which underlies this study.

Attitudes cannot be observed directly; they are demonstrated through behaviors such as the desire (or not) to learn another language, the inclination (or not) to approach speakers of other languages etc.

Language attitudes play an important role on language survival: positive attitudes toward a language may lead to language maintenance; negative attitudes, otherwise, tend to collaborate to the abandonment of a language and adoption of another.

Language loyalty (Weinreich 1953) is another key concept to explain the substitution of immigrant languages by Portuguese and, in some cases, the solidarity to one's own group's language. A bilingual speaker can be identified by linguistic traits derived from languages in contact. In certain situations, this arouses feelings of inferiority, discrimination or exclusion of the dominant group, 
which can lead to the abandonment of the minority language in favor of the majority one. On the other hand, this also stimulates feelings of familiarity, recognition and complicity among those who share these linguistic traits. Some participants of this study reported stigmatization during childhood, especially at school, for speaking a language variety different from Portuguese. On the other hand, most of the respondents expressed their pride in belonging to their ethnic groups and their wish of learning their ancestral languages (or even their regret for not being able to learn it).

Some authors (Lambert 1980, Clyne 1981, Dorian 1981, Lambert \& Freed 1982, Van Els et al. 1983, Silva-Corvalán 1987) use the terms "language attrition", "language loss", and "language death" to describe the intergenerational decline of the use of immigrant languages. These concepts seem to be broader than language shift and replacement, since it encompasses phenomena at societal and individual levels, such as the loss of domains that a language suffers in particular sociocultural context of contact and the reduction in the proficiency of a language that had been learned before by an individual (intra-generational damage). No matter which term is used, they all mean the gradual decline in language proficiency among migrants by lack of use, since the new generations are not exposed to their ancestral language within the family.

The situation of residual bilingualism (Dorian 1989, Mackey 2004), which occurs when speakers only retain some reduced skills in their ancestral languages, should also be mentioned. Having lost their utility due to the dominance of Portuguese, the immigrant languages in Brazil have started to be less and less used, being soon forgotten; in many cases, what remains is a rudimentary grammar and a small vocabulary.

Fishman (1972b) developed the notion of "domains of language use", which is influenced by these factors: topic (e.g. religion, family, work), relation between participants (e.g. preacher and audience, mother and daughter, boss and employee), and locale (e.g. church, home, business). Fishman's concept of domain is important because it helps explain the language mobility, since the shrinkage of domains of use of a particular language contributes to the diffusion process of another language.

\section{Methods}

The study is based on the corpora collected within a more comprehensive project involving researchers of various state universities in Paraná. The project, called Crenças e atitudes linguísticas: um estudo da relação do português com linguas de contato (Language beliefs and attitudes: a study on the relation between Portuguese and contact languages), was coordinated by Aguilera (2009) and covered eight multilingual communities in Paraná: Foz do Iguaçu, Santo Antônio do Sudoeste, Pranchita, Capanema, Marechal Cândido Rondon, Guaíra, Irati and Ponta Grossa. Most of these locations border Spanish-speaking countries (Argentina or Paraguay) and, therefore, are communities where language contact is more complex. 
Data collection involved interviews of eighteen participants in each community (except for Foz do Iguaçu, where 36 participants were interviewed), selected according to three variables: gender (male and female), age group (18-30, 31-50 and 51-70 years old) and level of education (elementary school, secondary school, and university). Participants have different backgrounds regarding their ethnic origins, but this was not a controlled variable in the study, since data were collected within a wider project in which this information was not considered when designing the questionnaire.

The interview was based on a questionnaire designed by Bergamaschi (2006), consisting of 47 questions comprising the assessment of the three elements of attitudes: cognition (thoughts), affection (feelings), and conation (behavior). Therefore, a mentalist approach was adopted, since under this perspective attitudes are viewed as an internal, mental state, which cannot be studied directly, but assessed through what can be measured, such as, for instance, a questionnaire/ interview (Lambert \& Lambert 1966, Fasold 1984). Examples of research questions in the project were: Which language(s) do you speak?; Which language(s) did your parents/grandparents speak to you when you were a child?; Which language(s) do people speak in your community?; Which language would you like to learn/speak?; Which language(s) should be included in the school curriculum?; Which language(s) is/are beautiful/ugly in your opinion?.

The analysis is centered on questions related to: a) the languages spoken by the respondents (currently and during their childhood), b) the languages spoken by their parents and grandparents, c) their level of awareness of local linguistic diversity, d) their willingness to speak or learn their ancestral languages, and e) their attitudes toward bi- and multilingualism and toward conservation of immigrant languages ${ }^{2}$.

This study focuses on the communities aforementioned, except for Foz do Iguaçu, which is not included due to its particular condition: it is a city characterized by intense tourism and business, situated next to both a Paraguayan and an Argentinian city, and where several ethnic groups of European and Asian origins live, which turns this place into a much more complex sociolinguistic context if compared to the other communities under investigation.

\section{The Communities: Socio-Historical Aspects}

Knowing the communities' history can be a key to understand the relationship between language and identity in their territories. Paraná, a state in the south of Brazil, is home to numerous ethnic groups: several indigenous peoples, European and Asian immigrants and descendants, Portuguese-Brazilians coming from other parts of Brazil, Spanish-speaking peoples coming from the bordering countries etc. This reality turns Paraná into a melting pot.

The communities under investigation are located in three main areas in Paraná: a) Irati and Ponta Grossa are situated in the central/southeast region; b) Guaíra and Marechal Cândido Rondon (henceforth MCR) are in the west; and c)

\footnotetext{
${ }^{2}$ The questions for the analysis are presented in the Tables 1 and 2, in the Results section.
} 
Capanema, Pranchita and Santo Antônio do Sudoeste (henceforth SAS) are in the southwest. The communities in the west and southwest are bordering Spanishspeaking countries. It is important to mention that indigenous peoples occupied all these areas prior to the arrival of other groups to colonize the territory.

As for the central/southeast region ${ }^{3}$ of Paraná, its history is mainly linked to the occupation by tropeiros ${ }^{4}$ and bandeirantes, and later by European immigrants. In Ponta Grossa, the first immigrant settlers were the Russo-Germans, who arrived there in 1870. Later, immigrants from different parts of Europe settled in the place: Poles, Dutch, Italians, Austrians, Swiss, Germans and Ukrainians. Asian immigrants (especially Syrians and Lebanese) also went to live in the region, which turns Ponta Grossa into a patchwork of cultures. For this reason, languages and cultures of the different groups seem to be more diluted if compared to other immigration contexts, and perhaps this is the reason why there are not many festivities related to a specific culture, except for the city's annual beer festival, Münchenfest.

Irati, by its turn, received the first wave of foreign settlers, consisting of Dutch, Ukrainians and Poles, in 1908, followed by the Germans, in 1909. From 1910 to 1912, more Poles and Ukrainians, in addition to Italian immigrants, settled in the locality. Differently from Ponta Grossa, Irati seems to be more concerned with maintaining the language, culture and identity of the immigrants. Media (radio programs and newspapers), religious or folkloric events, among other elements, contribute to spread the immigrants' languages and cultures. Irati promotes, for example, the Polish festival, the Festival of Nations, and the German festival (Deutsches Fest).

It is important to mention the role of religion in this scenario, because it is a very significant feature in Slavic peoples. According to Wachowicz (1982), both Poles and Ukrainians were endowed with a deep religious feeling, which greatly influenced the culture of this region. The church contributes to the maintenance of the Slavic languages and cultures with its various events, such as the Mass of Orthodox rite in Ukrainian, and the Christmas and Easter celebrations of the Slavic descendants. All these elements, combined with material symbols - as the Ukrainian religious architecture, artifacts, and the typical cuisine of different ethnic groups, for example - strengthen the ethnic identity of the various groups, contributing to conserving their language and culture.

The other localities are on the border with Spanish-speaking countries: Guaíra and MCR are in the west of Paraná, bordering Paraguay; and Capanema, Pranchita, and SAS are in the southwest, bordering Argentina. These regions experienced several historical movements linked to land occupation ${ }^{6}$.

\footnotetext{
${ }^{3}$ Wachowicz (1982) and Orreda (2007) provided historical data on this region.

${ }^{4}$ People who used to drive cattle, mules, and horses from one place to another.

5 People who penetrated Brazilian hinterlands in the early sixteenth century in search of mineral wealth, indigenous to enslavement or extermination of quilombos (places of refuge for African slaves and African descent).

${ }^{6}$ Wachowicz (1985), Gregory (2002), and Lazier (2003) provided historical data on the regions west and southwest.
} 
In the southwest, the first non-Indian inhabitants were the caboclos $^{7}$, who settled in the land as posseiros ${ }^{8}$. Argentinians and Paraguayans also occupied the region for the extraction of erva-mate ${ }^{9}$, but they left the region after the decrease of this activity. In the decades of 1940 and 1950, waves of immigrant descendants (predominantly of German, Italian, and Polish origins) coming from colonies previously formed in the other southern states settled in the region, to where they were attracted due to the possibility of buying land in possession of caboclos at low prices. Because of its fertile lands, the territory of the southwest of Paraná was disputed by Brazil and Argentina and by the states of Paraná and Santa Catarina, not to mention the involvement of a railway company, a colonization company and the posseiros in the land dispute.

It is important to mention that SAS is located next to San Antonio, Argentina, being only separated by the bridge over the Santo Antônio River. For this reason, the contact with Spanish speakers is more intense in this community than in Pranchita and Capanema. Efforts of maintaining the immigrant languages and cultures are not observed in SAS, since there are not any cultural events or practices promoting the use of these languages. The other two communities in the southwest of Paraná promote annual festivities: festivals with typical Italian food take place in Pranchita, where there is also an Italian dance group and an Italian coral; and the Kerbfest, with German music, dance, and cuisine takes place in Capanema.

In the west of Paraná, the first non-indigenous group to occupy the region was the Spaniards, who founded Jesuit reductions (or missions) ${ }^{10}$ in a vast territory they named Guayrá. Some years later, they were forced to abandon the region due to the successive attacks of bandeirantes, who destroyed the reductions and enslaved the Indians. Then, the region remained isolated until 1889, when the Military Colony was created in Foz do Iguaçu. After 1948, the intense migration process to the region resulted in the accelerated occupation of the territory, mainly by migrants from German, Italian, and Slavic origins coming from Santa Catarina and Rio Grande do Sul.

Guaíra is located near the Paraguayan city of Salto del Guairá, where shopping tourism is the driver of economic development. For this reason, contact between Brazilians (Portuguese speakers) and Paraguayans (Spanish and Guarani speakers) is very intense. As for MCR, the place was chiefly colonized by Germans, who tried to maintain their language and culture. As a result, Germanstyle architecture is representative in the city, and the municipal government and local businesspersons promote the annual Oktoberfest, with German (folkloric)

\footnotetext{
${ }^{7}$ In a general sense, caboclo (also known as mestizo) is the person of mixed descent (European and Indian). However, in the geo-historical context of research, caboclos were all the darkskinned people who had been raised in the backwoods and had habits and behavior of a country person (Wachowicz 1985).

${ }^{8}$ People who unlawfully occupied unused land (land pertaining to the federal government) in these regions.

${ }^{9}$ A plant, whose leaves are dried, chopped and ground into a powdery mixture for preparing a typical beverage in South America.

${ }^{10}$ A type of settlement for indigenous people in South America created by the Jesuit Order during the 17 th and 18 th centuries.
} 
music and dance, in addition to German typical cuisine. Religion also plays an important role in conserving the German varieties spoken in this community, since there is a close link between Lutheranism and the German language, as the Lutheran immigrants used to practice their faith entirely in this language.

\section{Results}

The questions aiming at identifying the languages spoken by the respondents (currently and during their childhood) and by their parents and grandparents showed that bilingualism is decreasing along generations in the investigated communities, revealing a situation of language loss in progress.

Table 1 shows the first group of research questions and the summary of results (percentages were rounded) in each community. For a better understanding of the table, the results for "P" include the participants (or their ascendants) who speak (or used to speak) only Portuguese; "P + IL" means that a mix between Portuguese and an immigrant language is/was spoken; "P + FL" means that a mix between Portuguese and a foreign language (i.e. a language not spoken in Brazil and generally learnt at school) is/was used; and "IL" means that exclusively immigrant language is/was used. Unknown answers (i.e. answers that, for any reason, were not given) are not included in the table.

Table 1 shows that none of the participants in Guaíra speak an immigration language. Ponta Grossa and SAS have the lowest rates of participants who still speak their ancestral language; MCR, Capanema and Irati have the highest rates of speakers who conserve their ancestral language, although they speak very little (according to their own answers), that is, they have limited proficiency in these languages. In these three places, there is high concentration of a specific ethnic group: German, Polish/Ukrainian and Italian, respectively. This situation may have contributed to the observed rates of maintenance. On the contrary, in the cities where different ethnic groups live together (Guaíra and Ponta Grossa), the speakers tend to abandon their ancestral languages.

It is noteworthy that, in some places, namely Guaíra, Capanema, SAS and Ponta Grossa, monolingualism in Portuguese is decreasing as there is an increase in the acquisition (via school) of a foreign language (either English or Spanish), as well as an increase in the use of Spanish due to daily interactions in the border communities. Table 2 shows the results of another group of research questions.

Data on the respondents' awareness of language diversity and their knowledge of the languages spoken locally (first column), show that most of them recognize the existing variety. Examples of words, phrases and sentences given by respondents are related mainly to greetings, conversational markers (in the case of Spanish), items of the typical cuisine, description of weather conditions, words for family members and expressions that label or characterize an ethnic group, such as nache lhude ("our people", in Ukrainian) and tutto buona gente ("[they are] all good people", in Italian), or even the obscene phrases commonly used by Italian descendants. This information highlights the existence of a language contact situation, but that is gradually dissolving, since what remains is a small vocabulary, characterizing the residual bilingualism (Dorian 1989, Mackey 2004). 
Some participants' answers (not shown in the table) indicate the domains of use of immigrant languages today: mostly in contexts in which ethnic groups gather, such as Masses and festive/folkloric events, and in rural communities, which, by being more isolated, tend to be more conservative with respect to the maintenance of immigrant languages. Even then, the immigrant languages are mainly spoken by aging adults. However, while these languages are used in limited, generally private contexts, Spanish (in the border locations) is used in broader, public contexts, especially by young speakers.

The results also showed that the vitality of immigration languages is mostly visible in Irati (Polish and Ukrainian), MCR (German), and Capanema (German and Italian). Considering that geographical and socio-cultural aspects are crucial for language maintenance, such vitality may be related to factors that contribute to conserve the languages and cultures of these groups, namely: religion, intra-ethnic marriage, cultural events and products, and relative geographic isolation (according to the respondents' answers to questions not included in this study).

Table 1. Intergenerational Bilingualism

\begin{tabular}{|c|c|c|c|c|}
\hline $\begin{array}{r}\text { Research } \\
\text { Questions }\end{array}$ & $\begin{array}{c}\text { Which } \\
\text { language(s) } \\
\text { do you } \\
\text { speak? }\end{array}$ & $\begin{array}{l}\text { Which } \\
\text { language did } \\
\text { your parents } \\
\text { use to speak to } \\
\text { you when you } \\
\text { were a child? }\end{array}$ & $\begin{array}{c}\text { Which language } \\
\text { did your } \\
\text { grandparents } \\
\text { use to speak to } \\
\text { you when you } \\
\text { were a child? }\end{array}$ & $\begin{array}{l}\text { Which language } \\
\text { did you use to } \\
\text { speak to your } \\
\text { parents/ } \\
\text { grandparents when } \\
\text { you were a child? }\end{array}$ \\
\hline Guaíra & $\begin{array}{l}\text { P: } 56 \% \\
P+\text { FL: } 44 \%\end{array}$ & $\begin{array}{l}\text { P: } 89 \% \\
\text { P + FL: } 6 \%\end{array}$ & $\begin{array}{l}\text { P: } 72 \% \\
\text { P + IL: } 6 \% \\
\text { IL: } 6 \%\end{array}$ & P: $61 \%$ \\
\hline $\begin{array}{l}\text { Marechal } \\
\text { Cândido } \\
\text { Rondon }(M C R)\end{array}$ & $\begin{array}{l}\text { P: } 61 \% \\
\text { P + IL: } 39 \%\end{array}$ & $\begin{array}{l}\text { P: } 33 \% \\
\text { P + IL: } 17 \% \\
\text { IL: } 50 \%\end{array}$ & $\begin{array}{l}\text { P: } 28 \% \\
\text { P + IL: } 17 \% \\
\text { IL: } 89 \%\end{array}$ & $\begin{array}{l}\text { P: } 56 \% \\
\text { P + IL: } 5 \% \\
\text { IL: } 39 \%\end{array}$ \\
\hline Capanema & $\begin{array}{l}\text { P: } 44 \% \\
\text { P + IL: } 28 \% \\
\text { P + FL: } 28 \%\end{array}$ & $\begin{array}{l}\text { P: } 67 \% \\
\text { P + IL: } 11 \% \\
\text { IL: } 22 \%\end{array}$ & $\begin{array}{l}\text { P: } 44 \% \\
\text { P + IL: } 17 \% \\
\text { IL: } 33 \%\end{array}$ & $\begin{array}{l}\text { P: } 50 \% \\
\text { P + IL: } 6 \% \\
\text { IL: } 33 \%\end{array}$ \\
\hline Pranchita & $\begin{array}{l}\text { P: } 50 \% \\
\text { P + IL: } 17 \% \\
\text { P + FL: } 28 \%\end{array}$ & $\begin{array}{l}\text { P: } 39 \% \\
\text { P + IL: } 33 \% \\
\text { IL: } 22 \%\end{array}$ & $\begin{array}{l}\text { P: } 17 \% \\
\text { P + IL: } 39 \% \\
\text { IL: } 33 \%\end{array}$ & $\begin{array}{l}\text { P: } 50 \% \\
\text { P + IL: } 44 \%\end{array}$ \\
\hline $\begin{array}{l}\text { Santo Antônio } \\
\text { do Sudoeste } \\
(\text { SAS) }\end{array}$ & $\begin{array}{l}\text { P: } 50 \% \\
\text { P + IL: } 11 \% \\
\text { P + FL: } 39 \%\end{array}$ & $\begin{array}{l}\text { P: } 72 \% \\
\text { P + IL: } 22 \% \\
\text { IL: } 6 \%\end{array}$ & $\begin{array}{l}\text { P: } 39 \% \\
\text { P + IL: } 39 \% \\
\text { IL: } 11 \%\end{array}$ & $\begin{array}{l}\text { P: } 72 \% \\
\text { P + IL: } 17 \% \\
\text { IL: } 6 \%\end{array}$ \\
\hline Irati & $\begin{array}{l}\text { P: } 72 \% \\
\text { P + IL: } 22 \% \\
\text { P + FL: } 6 \%\end{array}$ & $\begin{array}{l}\text { P: } 67 \% \\
\text { P + IL: } 22 \% \\
\text { IL: } 11 \%\end{array}$ & $\begin{array}{l}\text { P: } 33 \% \\
\text { P + IL: } 17 \% \\
\text { IL: } 28 \%\end{array}$ & $\begin{array}{l}\text { P: } 78 \% \\
\text { P + IL: } 11 \%\end{array}$ \\
\hline Ponta Grossa & $\begin{array}{l}\text { P: } 72 \% \\
\text { P + IL: } 6 \% \\
\text { P + FL: } 22 \%\end{array}$ & $\begin{array}{l}\text { P: } 83 \% \\
\text { P + IL: } 11 \% \\
\text { IL: } 6 \%\end{array}$ & $\begin{array}{l}\text { P: } 50 \% \\
\text { P + IL: } 28 \% \\
\text { IL: } 6 \%\end{array}$ & $\begin{array}{l}\text { P: } 78 \% \\
\text { P + IL: } 22 \%\end{array}$ \\
\hline
\end{tabular}


Table 2. Language Awareness and Attitudes Toward Bilingualism

\begin{tabular}{|c|c|c|c|}
\hline $\begin{array}{r}\text { Research } \\
\text { Questions }\end{array}$ & $\begin{array}{l}\text { Are there people who speak } \\
\text { differently from you in this } \\
\text { community? Which } \\
\text { languages do they speak? } \\
\text { Could you give any } \\
\text { examples? }\end{array}$ & $\begin{array}{l}\text { Would you like } \\
\text { to speak or } \\
\text { learn one of } \\
\text { the languages } \\
\text { spoken here? } \\
\text { Which one(s)? }\end{array}$ & $\begin{array}{c}\text { Do you think that } \\
\text { public use of these } \\
\text { languages should be } \\
\text { prohibited? } \\
\text { In your opinion, } \\
\text { should these languages } \\
\text { be taught at school? }\end{array}$ \\
\hline Guaíra & $\begin{array}{l}\text { Yes: } 94 \% \\
\text { Most remembered: Japanese } \\
\text { and Spanish } \\
\text { Examples mentioned: greetings, } \\
\text { discourse markers, languages } \\
\text { chunks for everyday } \\
\text { conversation, isolated words }\end{array}$ & $\begin{array}{l}\text { Yes: } 94 \% \\
\text { (mainly } \\
\text { Spanish; } \\
\text { English was } \\
\text { also mentioned) }\end{array}$ & $\begin{array}{l}\text { No prohibition: } 89 \% \\
\text { Yes (should be taught }- \\
\text { especially German): } \\
94 \%\end{array}$ \\
\hline $\begin{array}{l}\text { Marechal } \\
\text { Cândido } \\
\text { Rondon } \\
(M C R)\end{array}$ & $\begin{array}{l}\text { Yes: } 100 \% \\
\text { Most remembered: German } \\
\text { Examples mentioned: greetings }\end{array}$ & $\begin{array}{l}\text { Yes: 78\% } \\
\text { (mainly } \\
\text { German and } \\
\text { Italian) }\end{array}$ & $\begin{array}{l}\text { No prohibition: } 78 \% \\
\text { Yes (should be taught - } \\
\text { especially German): }\end{array}$ \\
\hline Capanema & $\begin{array}{l}\text { Yes: } 94 \% \\
\text { Most remembered: German, } \\
\text { Italian and Spanish } \\
\text { Examples mentioned: greetings, } \\
\text { family-related words, discourse } \\
\text { markers }\end{array}$ & $\begin{array}{l}\text { Yes: 94\% } \\
\text { (mainly } \\
\text { Spanish) }\end{array}$ & $\begin{array}{l}\text { No prohibition: } 94 \% \\
\text { Yes (should be taught }- \\
\text { especially Spanish): } \\
94 \%\end{array}$ \\
\hline Pranchita & $\begin{array}{l}\text { Yes: } 94 \% \\
\text { Most remembered: Italian } \\
\text { (followed by German) } \\
\text { Examples mentioned: obscene } \\
\text { expressions (Italian), greetings, } \\
\text { discourse markers }\end{array}$ & $\begin{array}{l}\text { Yes: } 100 \% \\
\text { (mainly Italian } \\
\text { and Spanish) }\end{array}$ & $\begin{array}{l}\text { No prohibition: } 78 \% \\
\text { Yes (should be taught - } \\
\text { especially Italian and } \\
\text { Spanish): } 100 \%\end{array}$ \\
\hline $\begin{array}{l}\text { Santo Antônio } \\
\text { do Sudoeste } \\
\text { (SAS) }\end{array}$ & $\begin{array}{l}\text { Yes: } 100 \% \\
\text { Most remembered: Spanish } \\
\text { Examples mentioned: greetings, } \\
\text { discourse markers, language } \\
\text { chunks for everyday } \\
\text { conversation, isolated words }\end{array}$ & $\begin{array}{l}\text { Yes: } 94 \% \\
\text { (mainly } \\
\text { Spanish) }\end{array}$ & $\begin{array}{l}\text { No prohibition: } 94 \% \\
\text { Yes (should be taught): } \\
61 \%\end{array}$ \\
\hline Irati & $\begin{array}{l}\text { Yes: } 100 \% \\
\text { Most remembered: Ukrainian, } \\
\text { Italian and Polish } \\
\text { Examples mentioned: greetings, } \\
\text { isolated words }\end{array}$ & $\begin{array}{l}\text { Yes: } 78 \% \\
\text { (mainly } \\
\text { Spanish, } \\
\text { English and } \\
\text { German) }\end{array}$ & $\begin{array}{l}\text { No prohibition: } 94 \% \\
\text { Yes (should be taught): } \\
89 \% \text { (but many } \\
\text { mentioned Spanish and } \\
\text { English) }\end{array}$ \\
\hline Ponta Grossa & $\begin{array}{l}\text { Yes: } 83 \% \\
\text { Most remembered: Polish, } \\
\text { Ukraine and Italian } \\
\text { Examples mentioned: greetings, } \\
\text { weather-related words, food- } \\
\text { related words, family-related } \\
\text { words, religious elements } \\
\text { (Ukraine) }\end{array}$ & $\begin{array}{l}\text { Yes: } 89 \% \\
\text { (mainly Italian) }\end{array}$ & $\begin{array}{l}\text { No prohibition: } 89 \% \\
\text { Yes (should be taught): } \\
61 \% \text { (especially English } \\
\text { and Spanish) }\end{array}$ \\
\hline
\end{tabular}

The results regarding the possibility of including immigrant languages in the school curriculum (Table 2, second column) show that most of the respondents think they should be taught in schools alongside other foreign languages of 
international prestige (English and Spanish). In other words, beside the concern about the symbolic value of English and Spanish as international languages, there is also the desire to access the legacy of the ancestral ethnic culture. In this sense, language education policies could promote language survival in the communities.

With regard to the questions on public use and teaching of the languages spoken in the communities (Table 2, third column), the answers show appreciation of ethnic languages and the need for bilingual education policies. There is, among the respondents, a positive attitude regarding the use of immigration languages both in the institutional context (school and church) and in everyday interactions. In general, they would not prohibit the public use of immigrant languages, and most of them advocated the people's right to speak their languages (freedom of speech) and to maintain their cultures through language (as an identity factor). Some respondents of the investigated communities demonstrated recognition that the appreciation of the language and culture of immigrants is a recent phenomenon. Cases of stigmatization of dialectal variety in childhood and the ban of speaking foreign languages were reported, as aforementioned.

Finally, it is important to mention that the extra linguistic factors (generational, educational, and gender) taken into account in the project conducted by Aguilera (2009) seem to not interfere significantly in the responses, as no relevant variation was found between respondents regarding these factors. Aguilera's project did not consider ethnic origin of respondents when designing the questionnaire, although some research questions (especially the ones reported in Table 1) permitted to infer this information. However, controlling this variable would be relevant to the information for this study.

\section{Final Remarks}

This study validates previous research (Silva-Poreli 2010, Pastorelli 2011, Lamb Fenner 2013, Corbari 2013), according to which language vitality is no longer observed between the Euro-descendants in the state of Paraná. Despite positive attitudes toward multilingualism and multiculturalism, and toward the respondents' own ancestral languages (such as the desire to learn/speak these languages), the European immigrants have been losing their ancestral language over a course of a few generations due to the dominance of Portuguese, the national language.

A few ethnic groups are indeed more successful than others in maintaining their ancestral language across subsequent generations, such as Irati and MCR. In this case, some factors seem to be associated with immigrant language survival: a) predominance of a specific ethnic group in the population; b) intra-ethnic marriage; c) parents' attitudes toward ancestral language survival; d) use of the ancestral language among family members; e) the role of religion; f) exposure to media; and g) the geo-social and historical context of the communities. Despite this, the new generations have been abandoning their ancestral languages. Most second-language learners now focus on Spanish and English, two of the most widespread languages in the world. 
The immigrant languages tend to disappear in a few years if proper language policy and planning, especially in the form of bilingual education, is not implemented in the investigated communities. Considering the Brazilian reality regarding the education system, it seems that the most effective form of bilingual education is the partial immersion, as proposed by Johnstone (2007).

There are overall positive attitudes toward bi- and multilingualism and a wish to conserve or revive the immigrant languages (e.g. there is great interest in learning and/or speaking these languages, as seen in Table 2). In other words, there are some indications of change in attitudes, as the immigrant languages are currently more positively valued than they were in the past. However, as Portuguese, the dominant and prestigious language, is currently widespread in Brazil, the attempt to reverse the language shift may be a difficult, if not an impossible, task. For this reason, a connection to language policies on a regional and national level is very important in the attempt of conserving the language diversity and cultural identities.

\section{Acknowledgments}

I would like to thank my doctoral supervisor, Professor Jacyra Andrade Mota, from the Federal University of Bahia, for the valuable suggestions given during the development of my doctoral research on language attitudes. I am particularly grateful for the assistance given by Professor Vanderci de Andrade Aguilera, especially for providing the data collected by the Project Crenças $e$ atitudes linguísticas: um estudo da relação do português com línguas de contato (Language beliefs and attitudes: a study on the relation between Portuguese and contact languages), under her coordination.

\section{References}

Aguilera VA (2009) Crenças e atitudes linguísticas: um estudo da relação do português com linguas de contato (Language beliefs and attitudes: a study on the relation between Portuguese and contact languages). State University of West of Paraná, Brazil.

Bergamaschi MCZ (2006) Bilingüismo de dialeto italiano-português: atitudes linguísticas (Italian-Portuguese bilingualism: language attitudes). Master Thesis. University of Caxias do Sul, Brazil.

Bolognini CZ, Payer MO (2005) Línguas de imigrantes (Languages of immigrants). Ciência e Cultura 57(2/Apr./June): 42-46.

Clyne MG (1981) Second language attrition and first language reversion among elderly bilinguals in Australia. In M Meid, K Heller (Eds.), Sprachkontakt als Ursache von Veränderungen der Sprach- und Bewußtseinsstruktur (Language contact as the cause of changes in the language and consciousness structure) (pp. 25-32). Institut fhür Sprachwissenschaft, Innsbruck, Austria.

Corbari CC (2013) Atitudes linguísticas: um estudo nas localidades paranaenses de Irati e Santo Antônio do Sudoeste (Language attitudes: a study in the localities of Irati and Santo Antônio do Sudoeste). Doctoral Thesis. Federal University of Bahia. Brazil. 
Dorian NC (1981) Language death: the life cycle of a Scottish Gaelic dialect. Philadelphia: University of Pennsylvania Press.

Dorian NC (1989) Investigating obsolence. London: Cambridge University Press.

Dorian NC (1999) Linguistic and ethnography fieldwork. In JA Fishman (Eds.), Handbook of language and ethnic identity (pp. 25-41). New York: Oxford University Press.

Fasold R (1984) The sociolinguistics of society. Oxford: Blackwell.

Fishman JA (1972a) The sociology of language: an interdisciplinary social science approach to language in society. Rowley, MA: Newbury House.

Fishman JA (1972b) Domains and the relationship between micro- and macrosociolinguistics. In JJ Gumperz, D Hymes (Eds.), Directions in Sociolinguistics: the Ethnography of Communication (pp. 435-453). Oxford: Basil Blackwell.

Fraga L (2008) Os holandeses de Carambeí: estudo sociolinguístico (The Dutch in Carambei: a sociolinguistic study). Doctoral Thesis. State University of Campinas, Brazil.

Gregory V (2002) Os euro-brasileiros e o espaço colonial: a dinâmica da colonização no Oeste do Paraná nas décadas de 1940 a 1970 (The Euro-Brazilians and the colonial space: the dynamics of colonization in Western Parana in the 1940s to 1970s). Cascavel, PR: Edunioeste.

Johnstone R (2007) Characteristics of immersion programmes. In O García, C Baker (Eds.), Bilingual education: an introductory reader (pp. 19-32). Toronto: Multilingual Matters.

Krug MJ (2004) Identidade e comportamento lingüístico na percepção da comunidade plurilíngüe alemão-italiano-português de Imigrante - RS (Identity and language behavior in the perception of the German-Italian-Portuguese plurilingual community of Imigrante - RS). Master Thesis. Federal University of Rio Grande do Sul, Brazil.

Lamb Fenner A (2013) Crenças e atitudes linguísticas: um estudo comparativo das línguas em contato em duas comunidades paranaenses (Language beliefs and attitudes: a comparative study on languages in contact in two communities of Paraná). Doctoral Thesis. Federal University of Bahia, Brazil.

Lambert RD (1980) Language skill attrition. Conference initiates research in new subfield. The Linguistic Reporter 23, 1-3.

Lambert RD, Freed BF (1982) The loss of language skills. Rowley, MA: Newbury House.

Lambert WW, Lambert WE (1966) Psicologia social (Social psychology). Rio de Janeiro: Zahar.

Lazier H (2003) Paraná: terra de todas as gentes e de muita história (Paraná: land of all people and lots of history). Francisco Beltrão, PR: Grafit.

Liebkind K (1999) Social Psychology. In JA Fishman (Eds.), Handbook of language and ethnic identity (pp. 140-151). New York: Oxford University Press.

Luersen RW (2009) A situação de contato plurilíngue no sul do Brasil (The plurilingual contact situation in southern Brazil). Visões 7(July/Dec.): 70-87.

Mackey WF (2004) Bilingualism in North America. In TK Bhatia, WC Ritchie (Eds.), The handbook of bilingualism (pp. 607-641). Oxford: Blackwell.

Moreno Fernández F (1998) Principios de sociolingüística y sociología del lenguaje (Principles of Sociolinguistics and Sociology of Language). Barcelona: Ariel.

Ogliari MM (2001) O bilingüismo português/ucraniano na família: influências sociodemográficas na situação bilíngüe familiar (Portuguese/Ukrainian bilingualism in the family: sociodemographic influences on the family's bilingual situation). Guairacá 17: 55-78.

Oliveira GM, Altenhofen CV (2011) O "in vitro" e o "in vivo" na política da diversidade linguística do Brasil: inserção e exclusão do plurilinguismo na educação e na 
sociedade (The "in vitro" and "in vivo" in the language diversity policies in Brazil: insertion and exclusion of plurilingualism in education and society). In T Raso, $\mathrm{H}$ Mello, CV Altenhofen (Eds.), Os contatos linguísticos do Brasil (The linguistic contacts of Brazil) (pp. 187-216). Belo Horizonte, MG: UFMG.

Orlandi EP (1998). Les discours fondateurs de la brésilienneté (The founding discourses of Brazilness). In I Muzart (Eds.), Naissance du Brésil moderne - 1500-1808 (Birth of Modern Brazil - 1500-1808) (131-142). Paris: PUF.

Orreda JM (2007) Irati, teu nome é história (Irati, your name is history). Curitiba: O debate, Irati.

Pastorelli DS (2011) Crenças e atitudes linguísticas na cidade de Capanema: um estudo da relação do português com línguas em contato (Language beliefs and attitudes in the city of Capanema: a study on the relation between Portuguese and languages in contact). Master Thesis. State University of Londrina, Brazil.

Pertile MT (2009) $O$ "talian" entre o italiano-padrão e o português brasileiro: manutenção e substituição linguística no Alto Uruguai Gaúcho (The "talian" between the standard Italian and Brazilian Portuguese: language maintenance and substitution in the Gaúcho Upper Uruguay). Doctoral Thesis. Federal University of Rio Grande do Sul, Brazil.

Renk VE (2009) Aprendi falar português na escola! O processo de nacionalização das escolas étnicas polonesas e ucranianas no Paraná (I learned to speak Portuguese at school! The process of nationalization of ethnic Polish and Ukrainian schools in Paraná). Doctoral Thesis. Federal University of Paraná, Brazil.

Silva-Corvalán C (1987) Language loss and development: some implications for linguistic theory. Second language acquisition: contributions and challenges to Linguistic Theory Conference, Stanford University Stanford, CA.

Silva-Poreli GA (2010) Crenças e atitudes linguísticas na cidade de Pranchita - PR: um estudo das relações do português com línguas em contato (Language beliefs and attitudes in the city of Pranchita - PR: a study on the relation between Portuguese and languages in contact). Master Thesis. State University of Londrina, Brazil.

Spolski B (1998) Sociolinguistics. Oxford: Oxford University Press.

Van Els T, de Bot K, Weltens B (1983) Language attrition research: a European perspective. Paper presented at the Meeting on Foreign Language and International Studies, Princeton, NJ, pp. 11-15.

Wachowicz RC (1982) História do Paraná (History of Paraná). Curitiba: Vicentina.

Wachowicz RC (1985) Paraná, Sudoeste: ocupação e colonização (Paraná, Southwest: occupation and colonization). Curitiba: Lítero-Técnica.

Weinreich U (1953) Languages in contact. The Hague: Mouton. 
